6062

Research Article

Journal of Extension Education

Vol. 30 No. 2, 2018

DOI:https://doi.org/10.26725/JEE.2018.2.30.6062-6066

\title{
Constraint Analysis of Farming on House Terraces
}

\author{
B. Binsa ${ }^{1}$ and G.S. Sreedaya ${ }^{2}$
}

\begin{abstract}
A study was carried out to identify the constraints in farming on house terraces and in the distribution of grow bags in Thiruvananthapuram Corporation in Kerala. The study was conducted in seven wards of Thiruvananthapuram Corporation namely Poojappura, Pettah, Manacaud, Kumarapuram, Karamana, Industrial Estate and Enchakkal. One hundred and five members of urban households involved in farming on house terrace, fifteen extension officials and thirty office bearers of selected residents' associations of the selected wards were the respondents of the study. Regarding the constraints perceived by the respondents on farming on house terrace, 'crop loss due to pests and diseases attack' was perceived as the major constraint and 'low quality grow bags and potting mixture issued by the private agencies' was the major constraint in the distribution and usage of grow bags as perceived by the respondents and office bearers of residents associations. 'Lack of timely availability of funds' was the major constraint in the scheme on farming on house terrace and growbag distribution as perceived by the extension officials.
\end{abstract}

Keywords: Constraints; Farming on house terraces; Kerala

\section{INTRODUCTION}

In the Indian state of Kerala, there are lot of initiatives from Directorate of Environment and Climate Change, Kerala Irrigation and Infrastructure Development Corporation and State Horticulture Mission to support and encourage the farming on house terraces. Still people are facing a lot of constraints in this field. The present investigation is therefore taken up to analyze the constraints in farming on house terraces including the distribution of grow bags. The results of the study would help in eliminating the bottlenecks in the present set up of farming on house terraces and help the planners, policy makers and administrators to further strengthen the farming on house terraces.

\section{METHODOLOGY}

The study was conducted in seven wards of Thiruvananthapuram Corporation namely Poojappura, Pettah, Manacaud, Kumarapuram, Karamana, Industrial Estate and Enchakkal. One hundred and five members of urban households involved in farming on house terrace, fifteen extension officials and thirty office bearers of selected residents associations of the selected wards were the respondents of the study. In this

1. PG Scholar and 2. Assistant Professor, Department of Agriculture Extension, College of Agriculture, Vellayani - 695522

Received : 10-05-2018; Accepted : 11-07-2018 
study, Delphi technique was followed by the researcher to identify the constraints. This technique was developed by Dalkey and Helmer (1963) and followed by Prakash (1990) and Carson (2005). Delphi technique was used for the present study in order to obtain data on the three aspects such as identification of major constraints, breaking them into component constraints and ranking them. It had three steps which includes two steps for identification of constraints and the third step for rating them according to the priority of importance.

\section{Step I}

In this phase, respondents were asked to list out the major problems which they felt important while involving in farming on house terrace. Personal interview was conducted with farmers practicing farming on house terrace and extension officials involved directly in farming on house terraces.

\section{Step II}

All the constraints obtained during the first phase were pooled together and was again presented to all the respondents. In this phase also data were collected through personal interview with the respondents. They were asked :

(1) To state if there is any change in previous responses.

(2) To state their agreement or disagreement to all the expressed constraints.

(3) To list out more specific constraints if any.

(4) To list out any other additional constraints.

\section{Step III}

In this phase, all the collected constraints were again pooled together. The respondents were asked to rate them in a five point continuum based on its importance ranging from 'most important', 'more important', 'undecided', 'less important' and 'least important'. The scores assigned were $5,4,3,2$ and 1 respectively.

Then the frequencies of respondents ranking each problem in each point of the continuum were found out. This was multiplied by weightage of each response category and was summed up to get the score of particular item. The constraint with the higher score value was considered as the most serious constraint, followed by other constraints in the order of decreasing score values based on the response. Thus the interview schedule would help to measure the perception of respondents about the constraints identified during the farming on house terraces and the distribution of grow bags.

\section{FINDINGS AND DISCUSSION}

Respondents in farming on house terrace had certain constraints identified through Delphi technique, which have been tabulated and are presented in Table 1. Crop loss due to pests and diseases attack was perceived as the major constraint.

Even though the incidence of pests and diseases are comparatively lower in farming on house terrace, it was perceived as a major constraint. Constraints faced by the respondents and office bearers of residents associations in the distribution and usage 
of grow bags are presented in Table 2. Low quality grow bags and potting mixture issued by the private agencies was perceived as the major constraint.
Constraints in farming on house terrace and grow bag distribution as perceived by the extension officials are presented in Table 3. Lack of timely availability of funds was perceived as the major constraint.

Table 1.

Constraints in Farming on House Terrace as Perceived by the Respondents

\begin{tabular}{|c|c|c|c|}
\hline SI. No. & Constraints & Score & Rank \\
\hline 1 & Crop loss due to pests and diseases attack & 409 & I \\
\hline 2 & $\begin{array}{l}\text { Difficulty in getting good quality inputs such as seed } \\
\text { material, biocontrol agents, biopesticides etc }\end{array}$ & 315 & II \\
\hline 3 & Difficulty in getting water on house terraces & 280 & III \\
\hline 4 & Inadequate extension support and lack of proper training & 267 & IV \\
\hline 5 & $\begin{array}{l}\text { Frequent damaging of drip emitters and difficulty to repair } \\
\text { them. }\end{array}$ & 226 & V \\
\hline 6 & $\begin{array}{l}\text { Difficulty in transferring inputs from the ground to house } \\
\text { terrace }\end{array}$ & 219 & $\mathrm{VI}$ \\
\hline 7 & $\begin{array}{l}\text { Difficulty in getting good quality potting mixture especially } \\
\text { with PGPR mix-1 }\end{array}$ & 204 & VII \\
\hline 8 & Seasonal variation & 201 & VIII \\
\hline 9 & Lack of time for house terrace farming activities & 187 & IX \\
\hline 10 & $\begin{array}{l}\text { Frequent wetting of ceilings will cause leakage problems } \\
\text { and floor would become dirty very fast }\end{array}$ & 158 & $\mathrm{x}$ \\
\hline 11 & Difficulty in getting labour & 145 & $X I$ \\
\hline 12 & $\begin{array}{l}\text { Kitchen wastes can't be converted into organic manure due } \\
\text { to the lack of physical facilities and technical knowhow. }\end{array}$ & 132 & XII \\
\hline 13 & $\begin{array}{l}\text { Lack of availability of cowdung and cow's urine for the } \\
\text { preparation of panchagavya and dasagavya. }\end{array}$ & 114 & XIII \\
\hline
\end{tabular}


Table 2.

Constraints in the Distribution and Usage of Grow Bags as Perceived by the Respondents and Office Bearers of Residents' Associations

$n=135$

\begin{tabular}{|c|l|c|c|}
\hline $\begin{array}{c}\text { SI. } \\
\text { No. }\end{array}$ & \multicolumn{1}{|c|}{ Constraints } & Score & Rank \\
\hline 1 & $\begin{array}{l}\text { Low quality grow bags and potting mixture issued by the } \\
\text { private agencies }\end{array}$ & 485 & I \\
\hline 2 & $\begin{array}{l}\text { Grow bags become damaged in every one or two crop } \\
\text { seasons and difficulty in replacing them }\end{array}$ & 360 & II \\
\hline 3 & High cost of grow bags & 174 & III \\
\hline 4 & Difficulty in disposing damaged plastic grow bags & 149 & IV \\
\hline
\end{tabular}

Table 3

Constraints in Farming on House Terrace and Grow Bag Distribution as Perceived by the Extension Officials

$(n=15)$

\begin{tabular}{|c|l|c|c|}
\hline SI. No. & \multicolumn{1}{|c|}{ Constraints } & Score & Rank \\
\hline 1 & Lack of timely availability of funds & 73 & I \\
\hline 2 & $\begin{array}{l}\text { Lack of adequate number of officials for executing the } \\
\text { project }\end{array}$ & 64 & II \\
\hline 3 & Less participation of farmers in the training sessions & 55 & III \\
\hline 4 & Difficulty to get good quality potting mixture & 51 & IV \\
\hline
\end{tabular}

Thiruvananthapuram Corporation is implementing a number of projects encouraging farming on house terraces. Inspite of this, they were not very successful due to inproper follow up activities. The enthusiasm showed in the initial establishment had faded away later. These agencies had also failed to impart training after identifying the training need analysis.
By ensuring timely availability and quality of inputs and infrastructural facilities, ervice of the experts at the time of necessity, frequent training programmes along with improved techniques, timely availability of fund for executing the projects etc, we could tackle the constraints to a great extent. Crop loss due to pests and diseases attack 
was perceived as the major constraint in farming on house terrace, which can be controlled to a great extent by daily observation and by mechanical methods such as hand picking, mechanical traps etc.

\section{CONCLUSION}

All the above cited measures would improve the overall scenario of farming on house terrace. This will not only help the overall development of the urban households, but also will help to bring more area under safe vegetable production helping the socio-economic and health position of Kerala.

\section{REFERENCES}

Carson, W.A. (2005). Successful implementation of enterprise resource planning software: A Delphi study. Digital Abstracts International. 66(1): 242.

Dalkey, N. C., \& Helmer, O. (1963). An experimental application of the Delphi method to the use of experts. Management Science. 9 (3): 458-467.

Prakash, R. (1989). Sequential analysis of constraints in increasing production of rice and coconut in Kerala. Unpublished PhD. Thesis, Kerala Agricultural University, Thrissur. 